\title{
Evaluation of Poultry Litter on Sorghum Straw Intake and Dry Matter Disappearance by Dry Cows ${ }^{1}$
}

\author{
Ramón Álvarez Zapata², Jorge Combellas Láres ${ }^{3}$
}

\begin{abstract}
An experiment was carried out to evaluate supplementation of sorghum straw (SS) with poultry litter (PL) in a single offering/day, and minerals and their effects on feed intake, sorghum straw dry matter disappearance (DMD) in nylon bags and rumen liquid ammonia $\mathrm{N}$ concentration. A 4x4 latin square design with 17-day periods and four rumen fistulated stalled cows was used to compare four treatments: (0) SS alone, (M) SS + mineral mixture offered ad libitum (P) SS + $1 \mathrm{~kg} /$ day of a concentrate with 83.5\% PL and (PM) SS + supplements used in M and P. The concentrate was offered in one meal and rumen $\mathrm{N}$ concentration increased to just over $100 \mathrm{mg} / \mathrm{L}$ between 1 and $3 \mathrm{~h}$ after feeding, decreasing to less than $50 \mathrm{mg} / \mathrm{L}$ after $7 \mathrm{~h}$, levels similar to those on treatments without PL. Dry matter disappearance at $72 \mathrm{~h}$ and feed intake increased by the addition of concentrate, but not by mineral supplementation. These results show that the effect of supplementation with PL was due mainly to degradable nitrogen and not by the minerals. A single offering/day is not enough to maintain recommended ammonia $\mathrm{N}$ concentrations during most of the day.
\end{abstract}

Key Words: calcium, crude protein, neutral detergent fiber, phosphorous, ruminal ammonia

\section{Avaliação da Cama de Frango sobre o Consumo e Desaparecimento da Matéria Seca da Palhada de Sorgo em Vacas Secas}

\begin{abstract}
RESUMO - Um experimento foi realizado para avaliar a suplementação de palhada de sorgo (PS) com cama de frango (CF), em oferta única, e com minerais, e seus efeitos sobre o consumo de ração, desaparecimento de matéria seca de PS (DMS), em sacos de nylon e a concentração de amônia no líquido ruminal. Quatro vacas confinadas e fistuladas no rúmen foram distribuídas em delineamento em quadrado latino $4 \times 4$, em período de avaliação de 17 dias, para comparar quatro tratamentos: (0) PS somente, (M) PS + mistura mineral ofertada ad libitum (P) PS + 1 kg/dia de um concentrado contendo 83,5\% de CF e (PM) PS + 1 kg/dia de suplementos usados em M e P. $\mathrm{O}$ concentrado foi oferecido em uma única refeição e a concentração de $\mathrm{N}^{-\mathrm{NH}_{3}}$ do rúmen alcançando valores um pouco acima de $100 \mathrm{mg} / \mathrm{L}$ entre 1 e 3 horas após o consumo da CF, com valores menores que $50 \mathrm{mg} / \mathrm{L}$ depois de 7 horas, níveis similares àqueles em tratamentos sem CF. O DMS às 72 horas e consumo de ração foram aumentados com a inclusão de concentrado ( $\mathrm{P}=0,0551)$, mas não com a suplementação por minerais. Os resultados obtidos indicam que o efeito da suplementação com CF deve-se, principalmente, ao nitrogênio degradável, e não aos minerais, e que uma alimentação por dia nãoé suficiente para manter a concentração de nitrogênio amoniacal no rúmen recomendada, durante a maior parte do dia.
\end{abstract}

Palavras-chave: amônia ruminal, cálcio, fibra em detergente neutro, fósforo, proteína bruta

\section{Introduction}

Low quality forages are the main source of cattle diets in most tropical and sub-tropical regions of the world. They are typically less than $55 \%$ digestible, have less than $8 \%$ crude protein and $10 \%$ sugars and starch, and are commonly deficient in minerals (Leng, 1990). Moreover, low cost resources available to satisfy these deficiencies are limited in these areas.

A way to improve the utilization of these fibrous, bulky and poor quality materials through feed supplementation must take into account the requirements of rumen microorganisms (Leng, 1993).
It is known that animal manure can be a valuable source of crude protein and energy for ruminants (Deshck et al., 1998). Poultry litter has acquired an important role as source of nitrogen and other elements to satisfy some nutrient deficiencies in poor quality fibrous feeds. Its availability as a ruminant feed is due to the rapid growth of the poultry industry in tropical countries and the fact that its high fibre and non-protein nitrogen content limits its use for non-ruminant species.

Uric acid is the main nitrogen $(\mathrm{N})$ compound present in poultry litter and is used as a source of degradable protein in the rumen that is used efficiently

\footnotetext{
1 Project sponsored by FUNDACITE ARAGUA, CDCH-UCV.

2 Profesor Agregado del Departamento de Zootecnia/UCV. E.mail: ramon.alvarez@bbsrc.ac.uk

3 Profesor Titular del Departamento de Zootecnia/UCV.
} 
by the rumen microorganisms (Bierman et al., 1996). The amount of poultry litter required to supply $\mathrm{N}$ to rumen microorganisms in these conditions is rather small. It is therefore consumed quickly at feeding time which probably limits the concentration of rumen ammonia $\mathrm{N}$ necessary to satisfy bacteria growth requirements during the rest of the day. Pereira et al. (2001) calculated that ammonia $\mathrm{N}$ into the rumen of steers fed on a diet of sugar cane supplemented with urea and poultry litter was greater than $150 \mathrm{mg} / \mathrm{l}$ at 3 hours and less than $50 \mathrm{mg} / \mathrm{l}$ at 8 hours after feeding. The latter concentration is considered to be the minimum necessary to maximize microbial growth and rate of digestion of rumen contents (Satter \& Slyter, 1974). Poultry litter is also a source of mineral elements, but there is no information to quantify this contribution to improvement of the utilization and intake of low quality forages.

The Brazilian Minister of Agriculture, by the Normative Instruction number 15 of July 17 of 2001, in the second article, prohibited in all Brazilian territory, the utilization of feeds that contain mammalian protein in ruminant feeding, including poultry litter, but this resource is intensively used in other countries. Therefore, an experiment was carried out on Maracay, Venezuela with rumen fistulated bovines to evaluate the influence of the supplementation of sorghum straw with poultry litter offered in a single feed and/or a mineral mixture on feed intake, sorghum straw dry matter disappearance and rumen ammonia $\mathrm{N}$ concentration.

\section{Materials and Methods}

The experiment was carried out at the experimental farm of the Instituto Nacional de Investigaciones Agrarias, located in Maracay, Venezuela, at an altitude of $450 \mathrm{~m}$, with annual averages of $852 \mathrm{~mm}$ rainfall, $31.5^{\circ} \mathrm{C}$ maximum temperature, $18.5^{\circ} \mathrm{C}$ minimum temperature and 65 to $80 \%$ relative humidity.

A latin square $4 \times 4$ experimental design with four animals, during a 17-day period, was used to compare the following feeding treatments:

0 : only sorghum straw

M: sorghum straw plus mineral mixture offered ad libitum

P: sorghum straw plus $1 \mathrm{~kg} /$ day of concentrate (83.5\% poultry litter)

PM: sorghum straw plus $1 \mathrm{~kg} /$ day concentrate $(83.5 \%$ poultry litter) plus mineral mixture offered ad libitum.
The first 7 days were of adaptation to diets; straw and total intake was determined between days 8 and 14 and from day 15 to 17 rumen measurements were carried out.

Four adult dry Brahman $x$ Holstein cows of $440 \mathrm{~kg}$ average live weight (LW) provided with rumen cannulas of $12 \mathrm{~cm}$ internal diameter were individually housed in partially roofed pens of $4 \times 8 \mathrm{~m}^{2}$, with water available ad libitum. Sorghum (Sorghum bicolor) straw was brought from a commercial farm in bales of about $12 \mathrm{~kg}$ fresh weight and was offered without chopping at 06:00 h, allowing a refusal of $15 \%$. The concentrate had $83,5 \%$ poultry litter, $15 \%$ cotton seed meal and $1.5 \%$ common salt and was also offered at 06:00 h. All poultry litter used was brought two weeks before starting the trial from a nearby farm and conserved in one pile covered with a black polythene sheet within a shed with concrete floor.

A commercial mineral mixture (Nutriservi, Maracay) was used, with the following composition according to manufacturers: $20 \% \mathrm{Ca}, 10 \% \mathrm{P}, 9 \% \mathrm{Na}$, $0.5 \% \mathrm{Mg}, 0.6 \% \mathrm{~S}, 0.25 \% \mathrm{Mn}, 0.25 \% \mathrm{Cu}, 20 \mathrm{ppm} \mathrm{Co}$, $20 \mathrm{ppm}$ Se and $80 \mathrm{ppm}$ I.

Samples of concentrate and straw offered and refused were taken daily during the intake measurement period, dried at $70^{\circ} \mathrm{C}$ during $48 \mathrm{~h}$ and dry matter calculated to estimate total and sorghum straw intake. Samples were ground through a $1 \mathrm{~mm}$ screen and analysed for dry matter, ash, ether extract and crude protein (AOAC, 1984), neutral detergent fibre (Goering \& Van Soest, 1970), phosphorous (Fick et al., 1979) and calcium (Harris \& Popat, 1954).

A sorghum straw sample was taken at the beginning of the trial, ground through a $3 \mathrm{~mm}$ screen and used to estimate dry matter disappearance (DMD) in nylon bags of $5 \times 10 \mathrm{~cm}$ and 48 ì pore size (fabric by Tripette $\&$ Renaud, France), following the procedure described by Ørskov et al. (1980). Each bag was filled with $5 \mathrm{~g}$ of straw and 10 bags were introduced in the rumen of each cow at 06:00 $\mathrm{h}$ of day 15 and a pair of them taken out at $6,12,24,48$ and $72 \mathrm{~h}$, washed with tap water and dried for $24 \mathrm{~h}$ at $100{ }^{\circ} \mathrm{C}$, to estimate by difference the dry matter disappearance at each time.

At day 15 , about $30 \mathrm{~mL}$ rumen fluid samples were taken at 6 a.m. (before meal), 7 a.m., 9 a.m., 11 a.m., 1 p.m., 4 p.m., 7 p.m. and 10 p.m., filtered through cheese cloth into $50 \mathrm{~mL}$ plastic flasks, 8 drops of $97 \%$ sulphuric acid were added and all flasks were stored frozen. The ammonia $\mathrm{N}$ content on the samples was later analysed by the distillation phase of the Kjeldahl method (AOAC, 1984).

R. Bras. Zootec., v.34, n.2, p.584-588, 2005 
An analysis of variance was carried out to evaluate the influence of treatments on total and straw intake, ammonia $\mathrm{N}$ concentration and DMD at sampling times. Means were compared by using the Multiple Range Test of Duncan (Steel \& Torrie, 1980).

\section{Results and Discussion}

The chemical composition of sorghum straw, poultry litter and concentrate is shown in Table 1. As expected these were high contents of crude protein, calcium and phosphorous in the concentrate and low concentrations of these fractions in the straw. The average crude protein content in poultry litter was similar or inferior to other values reported in the literature (Deshck et al., 1998; Bhattacharya and Fontenot, 1966; Morales et al., 2002). The factors that contributed to the low concentration of protein were the high levels of fibre (NDF) $(47.8 \%)$ and ash $(31.0 \%)$, suggesting that the poultry litter contained a high proportion of original base material and was contaminated with soil, respectively.

The DMD in nylon bags of the sorghum straw without supplements did not improve with the supplementation with minerals or concentrate at any incubation time $(p>0.05)$ (Table 2), but there was a trend towards an increase with concentrate supplementation when the bags remained $72 \mathrm{~h}$ in the rumen $(p=0.055)$, reaching values of 48.2 and $45.0 \%$ in P and PM, respectively.

Ammonia $\mathrm{N}$ concentration in rumen fluid was below $40 \mathrm{mg} / \mathrm{L}$ just before feeding, at 6 p.m., in all treatments, and increased to over $100 \mathrm{mg} / \mathrm{L}$ one hour after in the treatments with concentrate. This peak was maintained for $3 \mathrm{~h}$ and decreased to about $60 \mathrm{mg} / \mathrm{L}$, $5 \mathrm{~h}$ after feeding. During this period, from 1 to $5 \mathrm{~h}$ after feeding, the values were higher than in the treatments without poultry litter $(p<0.05)$, and decreased to about $50 \mathrm{mg} / \mathrm{L}$ at the following sampling $7 \mathrm{~h}$ after feeding. At subsequent samplings and until the next feeding, ammonia $\mathrm{N}$ levels were below $50 \mathrm{mg} / \mathrm{L}$ and no differences between treatments were observed $(p>0.05)$. Ammonia $\mathrm{N}$ concentrations in all samplings of 0 and $\mathrm{M}$ were below $38 \mathrm{mg} / \mathrm{L}$ and no differences were observed between them.

The sorghum straw DM intake offered alone was low, $5.2 \mathrm{~kg} / \mathrm{day}$, equivalent to $1.2 \%$ of LW (Table 4 ). It was not increased by mineral supplement and intake remained exactly the same, but concentrate supplementation increased sorghum straw intake by about $0.8 \mathrm{~kg} \mathrm{DM} /$ day and total intake in $1.7 \mathrm{~kg} \mathrm{DM} /$ day.
Table 1 - Chemical composition of feeds

\begin{tabular}{lccc}
\hline & $\begin{array}{c}\text { Sorghum } \\
\text { straw }\end{array}$ & $\begin{array}{c}\text { Poultry } \\
\text { litter }\end{array}$ & Concentrate \\
\hline Dry matter & 93.1 & 84.9 & 88.9 \\
Crude protein & 3.3 & 23.6 & 25.3 \\
Ash & 7.8 & 31.0 & 25.2 \\
Ether extract & - & 3.3 & 2.2 \\
Neutral detergent fiber & 71.9 & 47.8 & 45.6 \\
Calcium & 0.33 & 3.81 & 2.03 \\
Phosphorous & 0.17 & 2.19 & 1.51 \\
\hline
\end{tabular}

Table 2 - Dry matter disappearance of sorghum straw (\%) at incubation times

\begin{tabular}{lcccccc}
\hline Incubation & \multicolumn{4}{c}{ Treatment } & SEM & Significance \\
\cline { 2 - 5 } time (h) & 0 & $\mathrm{M}$ & $\mathrm{P}$ & $\mathrm{PM}$ & & \\
\hline 6 & 12.5 & 11.5 & 11.8 & 11.6 & 1.02 & 0.9050 \\
12 & 12.4 & 11.8 & 12.9 & 13.6 & 1.10 & 0.6984 \\
24 & 22.2 & 19.0 & 24.1 & 25.9 & 2.26 & 0.2209 \\
48 & 34.2 & 29.8 & 37.7 & 36.0 & 3.04 & 0.3374 \\
72 & 38.9 & 40.2 & 48.2 & 45.0 & 2.36 & 0.0551 \\
\hline
\end{tabular}

SEM: Standard error of mean.

0 : only sorghum straw.

M: sorghum straw plus mineral mixture offered ad libitum. $P$ : sorghum straw plus $1 \mathrm{~kg} /$ day of concentrate $(83.5 \%$ poultry litter). PM: sorghum straw plus $1 \mathrm{~kg} /$ day concentrate $(83.5 \%$ poultry litter) plus mineral mixture.

Mineral supplementation did not influence DMD of sorghum straw or its intake in this experiment (Tables 2 and 4), which could be related to the mineral content of the material used and the low requirements of the animals. Only calcium and phosphorous were analyzed and their contents in the sorghum straw were of 0.33 and $0.17 \%$ respectively (Table 1 ), values slightly lower than averages of 0.38 and $0.21 \%$ observed by Minson (1990) in tropical grasses. The daily intake of these elements was of 17.2 and $8.8 \mathrm{~g} /$ day respectively, enough in the case of calcium to fulfil the $17.8 \mathrm{~g} /$ day required by an animal at maintenance (NRC, 2000), but slightly too low to satisfy the $12.2 \mathrm{~g} /$ day of phosphorous needed. However, to obtain responses to phosphorous, it has to be the principal deficiency, with concentrations below $0.12-0.15 \%$, adequate supplies of energy in the forage and $\mathrm{N}$ levels above $1.5 \%$ (Winks, 1990), conditions which were not met in the present case.

The main effect of supplementation with the concentrate based on poultry litter was a rapid increase in ammonia $\mathrm{N}$ content in rumen fluid, from values under $40 \mathrm{mg} / \mathrm{L}$ to over $100 \mathrm{mg} / \mathrm{L}$, but after $3 \mathrm{~h}$ they decreased and had returned to the initial levels $10 \mathrm{~h}$ after feeding (Table 3). Satter \& Slyter (1974) 
Table 3 - Ammonia nitrogen concentration (mg/L) of rumen fluid samples at different sampling times

\begin{tabular}{lcccccc}
\hline \multirow{2}{*}{$\begin{array}{l}\text { Time } \\
\text { (hour) }\end{array}$} & \multicolumn{4}{c}{ Treatment } & SEM & Significance \\
\cline { 2 - 5 } & 0 & $\mathrm{M}$ & $\mathrm{P}$ & $\mathrm{PM}$ & & \\
\hline $06: 00$ & 20 & 19 & 33 & 39 & 9.4 & 0.3072 \\
07:00 & $36 \mathrm{~b}$ & $19 \mathrm{~b}$ & $129 \mathrm{a}$ & $100 \mathrm{a}$ & 12.9 & 0.0002 \\
09:00 & $38 \mathrm{~b}$ & $22 \mathrm{~b}$ & $114 \mathrm{a}$ & $105 \mathrm{a}$ & 13.0 & 0.0005 \\
$11: 00$ & $33 \mathrm{~b}$ & $31 \mathrm{~b}$ & $60 \mathrm{a}$ & $59 \mathrm{a}$ & 7.4 & 0.0216 \\
$13: 00$ & 31 & 16 & 45 & 54 & 9.3 & 0.0630 \\
$16: 00$ & 22 & 31 & 31 & 43 & 9.6 & 0.5271 \\
$19: 00$ & 19 & 20 & 28 & 35 & 7.1 & 0.3944 \\
$22: 00$ & 23 & 21 & 36 & 47 & 9.8 & 0.2577 \\
\hline
\end{tabular}

SEM: Standard error of the mean.

$a, b$ Means in the same row with different letters are significantly different $(p<.05)$, by Duncan test.

0 : only sorghum straw.

M: sorghum straw plus mineral mixture offered ad libitum $\mathrm{P}$ : sorghum straw plus $1 \mathrm{~kg} /$ day of concentrate (83.5\% poultry litter). PM: sorghum straw plus $1 \mathrm{~kg} /$ day concentrate $(83.5 \%$ poultry litter) plus mineral mixture.

suggested that $50-80 \mathrm{mg} / \mathrm{L}$ is the optimum level to maximise microbial growth and some more recent information reviewed by Leng (1990) indicates that it could be higher in low quality feeds. However, even the former levels were only reached during a short period of $6 \mathrm{~h}$ daily and remaining under $50 \mathrm{mg} / \mathrm{L}$ during the rest of the day. In the control treatment, without nitrogen supplements, the ammonia $\mathrm{N}$ concentrations varied between 19 and $38 \mathrm{mg} / \mathrm{L}$, and were always below desired values to optimise microbial growth.

An adequate level of ammonia $\mathrm{N}$ is also essential for optimising forage digestion, but was not achieved in the $\mathrm{N}$ supplemented animals during most of the day and probably the potential DMD of sorghum straw was not reached. But the addition of concentrate improved the rumen environment to some extent in relation to control animals and DMD increments with time were observed, resulting in an increase of 6-10 digestibility units $(p<0.10)$ at $72 \mathrm{~h}$ of incubation (Table 2$)$.

Concentrate supplementation resulted in a significant increase in sorghum straw intake, from 5.2 to $6.0 \mathrm{~kg} \mathrm{DM} /$ day (Table 4), and two factors could have contributed toit. The first is the improvementin digestibility and its positive relationship with intake of low quality forages (Conrad et al., 1964). The second factor is a higher microbial cell to volatile fatty acids ratio derived from digestion as a result of the $\mathrm{N}$ supplied and its positive effect on intake (Leng, 1990). An intake increase of low quality forages after duodenal $\mathrm{N}$ infusions was observed in early studies by Egan (1965) and Egan \& Moir (1965), and more recent experiences with cattle have shown large Intake increments without major variations in roughage digestibility in low quality grass hays supplemented with protein sources (Fleck et al., 1988; Hannah et al., 1991).

However, in the present study, a level of $\mathrm{N}$ concentration sufficient to optimise rumen function was not achieved, limiting microbial protein synthesis and possibly greater intake values. In an experiment carried out before at this Institute (Mata \& Combellas, 1992), the supplementation of Trachypogon sp., a low quality native grass, with urea molasses blocks resulted in large and uniform increment on rumen fluid ammonia $\mathrm{N}$ concentration, from less than $7 \mathrm{mg} /$ $\mathrm{L}$ to over $100 \mathrm{mg} / \mathrm{L}$ throughout the day, and a $60 \%$ increase in herbage intake. In consequence, sources of degradable $\mathrm{N}$, such as poultry litter, should not be offered in a single feed if its purpose is to increase ammonia $\mathrm{N}$ content in rumen fluid in order to enhance digestibility and intake.

Table 4 - Sorghum straw and total dry matter intake (DM) by dry cows

\begin{tabular}{|c|c|c|c|c|c|c|}
\hline \multirow[t]{2}{*}{ Intake (kg DM/day) } & \multicolumn{4}{|c|}{ Treatment } & \multirow[t]{2}{*}{ SEM } & \multirow[t]{2}{*}{ Significance } \\
\hline & 0 & $\mathrm{M}$ & $\mathrm{P}$ & $\mathrm{PM}$ & & \\
\hline Sorghum straw & $5.2 \mathrm{~b}$ & $5.2 \mathrm{~b}$ & $6.0 \mathrm{a}$ & $5.9 \mathrm{a}$ & 0.20 & 0.0010 \\
\hline Total DM & $5.2 \mathrm{~b}$ & $5.2 \mathrm{~b}$ & $6.9 \mathrm{a}$ & $6.8 \mathrm{a}$ & 0.20 & 0.0001 \\
\hline
\end{tabular}

SEM: Standard error of the mean.

$a, b$ Means in the same row with different letters are significantly different $(p<0.05)$, by Duncan test.

0 : only sorghum straw.

M: sorghum straw plus mineral mixture offered ad libitum

$\mathrm{P}$ : sorghum straw plus $1 \mathrm{~kg} /$ day of concentrate $(83.5 \%$ poultry litter).

PM: sorghum straw plus $1 \mathrm{~kg} /$ day concentrate $(83.5 \%$ poultry litter) plus mineral mixture.

R. Bras. Zootec., v.34, n.2, p.584-588, 2005 


\section{Conclusions}

These results show that feed intake and sorghum straw utilization are increased with poultry litter, but supplying it at low levels in one meal is not enough to maintain recommended ammonia $\mathrm{N}$ concentrations during most of the day. In consequence, poultry litter should be offered during all day in order to enhance digestibility and intake.

\section{Literature Cited}

ASSOCIATION OF OFFICIAL AGRICULTURAL CHEMISTS - AOAC. Official methods of analysis. 14.ed. Washington, D.C.: 1984. 1015p.

BIERMAN, S.; KLOPFENSTEIN, T.; STOCK, R.; HEROLD, $D$. Dried poultry waste as a nonprotein nitrogen source for ruminants. Nebraska Beef Report. The Agricultural Research Division. Institute of Agriculture and Natural Resources. University of Nebraska. 1996. p.31-33.

BHATTACHARYA, A.N.; FONTENOT, J.P. Intake and digestion by Holstein steers consuming diets based on litter harvested after different numbers of broiler growing periods or with molasses addition before deep-stacking. Journal of Animal Science, n.25, p.2331-2335, 1966.

CONRAD, H.R.; PRATT, A.D.; HIBBS, J.W. Regulation of food intake in dairy cows. I. Change in importance of physical and physiological factors with increasing digestibility. Journal of Dairy Science, n.47, p.54-62, 1964.

DESHCK, A.; ABO-SHEHADA, M.; ALLONBY, E. et al. Assessment of the nutritive value for ruminants of poultry litter. Animal Feed Science and Technology, n.73, p.29-35, 1998.

EGAN, A.R. Nutritional status and intake regulation in sheep. 2. The influence of sustained infusions of casein or urea upon voluntary intake of low-protein roughages by sheep. Australian Journal of Agricultural Research, n.16, p.451-462, 1965.

EGAN, A.R.; MOIR, R.J. Nutritional status and intake regulation in sheep. 1. Effects of duodenally infused single doses of casein, urea and propionate upon voluntary intake of a lowprotein roughage by sheep. Australian Journal of Agricultural Research, n.16, p.437-449, 1965.

FICK, K.; MCDOWELL, L.; MILLES, P. et al. Análisis por espectrofotometría de absorción atómica. In: Métodos de análisis de minerales para tejidos de plantas y animales. 2.ed. Latin American Mineral Research Program, University of Florida, 1979. p.701-702.

FLECK, A.T.; LUSBY, K.S.; OWENS, F.N. et al. Effects of corn gluten feed on forage intake, digestibility and ruminal parameters of cattle fed native grass hay. Journal of Animal Science, n.66, p.750-757, 1988.

GOERING, H.K.; Van SOEST, P.J. Forage fiber analysis. Agricultural Research Service, USDA, Agricultural Handbook n.379, 1970. p.21-30.
HANNAH, S.M.; COCHRAN, R.C.; VANZANT, E.S. et al. Influence of protein supplementation on site and extent of digestion, forage intake and nutrient flow characteristics in steers consuming dormant blue-range forage. Journal of Animal Science, n.60, p.2624-29633, 1991.

HARRIS, W.; POPAT, P. Determination of phosphorus content of lipids. Journal of the American Oil Chemistry Society, n.32, p.124-127, 1954.

LENG, R.A. Factors affecting the utilization of "poor quality" forages by ruminants particularly under tropical conditions. Nutrition Research and Reviews, n.3, p.277-303, 1990.

LENG, R.A. Quantitative ruminant nutrition - A green science. Australian Journal of Agricultural Research, n.44, p.363-380, 1993.

MATA, D.; COMBELLAS, J. Influence of multinutrient blocks on intake and rumen fermentation of dry cows fed basal diets of Trachypogon sp. and Cynodon plectostachyus hays. Livestock Research for Rural Development, n.4, p.40-48, 1992.

MINSON, D.J. Forage in ruminant nutrition. San Diego: Academic Press, 1990. p.21-30.

MORALES, H.; GUTIERREZ, E.; BARRADAN, H. El uso de la cama de pollo de Buena calidad mejora la productividad de bovines en crecimiento en engorda. Técnica Pecuária en México, n.40, v.1, p.1-15, 2002.

NATIONAL RESEARCH COUNCIL - NRC. Nutrient requirements of beef cattle. 8.rev.ed. Washington, D.C: National Academy Press, 2000. 233p.

ØRSKOV, E.R.; DE HOVELL F.D.; MOULD, F. The use of the nylon bag technique for the evaluation of feedstuffs. Tropical Animal Production, n.5, p.195-213, 1980.

PEREIRA, E.S.; QUEIROZ, A.C.; FONSECA, D.M. et al. Fontes nitrigenadas e uso de Sacharomyces cerevisiae em dietas à base de cana-de-açucar para novilhos: consumo, digestibilidad, balaço nitrogenado e parâmetros ruminais. Revista Brasileira do Zootecnia, n.30, p.563-572, 2001.

SATTER, L.D.; SLYTER, L.L. Effect of ammonia concentration on microbial production in vitro. British Journal of Nutrition, n.32, p.194-201, 1974.

STEEL, R.G.D.; TORRIE, J.H. Principles and procedures of statistics. 2.ed. New York: McGraw-Hill, 1980. 633p.

WINKS, L. Phosphorus and milk production in northern Australia. 1. Responses to phosphorus by ruminants. Tropical Grasslands, n.24, p.140-148, 1990.
Recebido em: $17 / 11 / 03$ Aceito em: 22/03/04 